\title{
Direct impregnation method for preparing sulfated zirconia supported on mesoporous silica
}

\author{
Chang-Lin Chen ${ }^{\text {a,b }}$, Tao Li ${ }^{\text {a }}$, Soofin Cheng ${ }^{\text {a }}$, Hong-Pin Lin ${ }^{\text {a,c }}$, \\ Chetan J. Bhongale ${ }^{\mathrm{a}}$, Chung-Yuan Mou ${ }^{\mathrm{a}, *}$ \\ a Department of Chemistry, National Taiwan University, 1 Roosevelt Road, Section 4, Taipei 106, Taiwan \\ ${ }^{\mathrm{b}}$ College of Chemical Engineering, Nanjing University of Technology, Nanjing 210009, China \\ ${ }^{\mathrm{c}}$ Institute of Atomic and Molecular Science, Academia Sinica, Taipei 106, Taiwan
}

Received 1 October 2001; accepted 4 October 2001

\begin{abstract}
A new method has been developed to prepare sulfated zirconia $\left(\mathrm{S}-\mathrm{ZrO}_{2}\right)$ supported on mesoporous silica. With direct exchange of metal containing precursors for the surfactants in the as-synthesized MCM-41 materials, the problem of fill-up of the mesoporous structure was avoided and high sulfur content was achieved. By using this method, the composite of S- $\mathrm{ZrO}_{2} / \mathrm{MCM}-41$ with $\mathrm{ZrO}_{2}$ content higher than $60 \mathrm{wt} . \%$ can be easily obtained without serious blockage of the pore structure of MCM-41. Nevertheless, the pore size and pore volume of the resultant $\mathrm{S}-\mathrm{ZrO} \mathrm{Z}_{2} / \mathrm{MCM}-41$ composites were found to vary markedly with the loading of $\mathrm{ZrO}_{2}$. The strong acidic character of the obtained composites was examined by using them as catalysts in $n$-butane isomerization. Introduction of other metals such as aluminum as promoter into $\mathrm{S}-\mathrm{ZrO}_{2} / \mathrm{MCM}-41$ can be easily conducted by the direct impregnation method. (C) 2001 Published by Elsevier Science B.V.
\end{abstract}

Keywords: Direct impregnation; Sulfated zirconia; Mesoporous silica; Butane isomerization

\section{Introduction}

Mesoporous molecular sieves have potential applications as catalysts for processing large molecules, especially those encountered in petroleum refining and pharmaceutical industries, because of their tunable uniform pore structures $(2-30 \mathrm{~nm})$ and large surface areas $\left(\sim 1000 \mathrm{~m}^{2} / \mathrm{g}\right)$ [1,2]. However, the weak strength of acidity arising from the

\footnotetext{
${ }^{*}$ Corresponding author. Fax: +886-2-23660954.

E-mail address: cymou@ccms.ntu.edu.tw (C.-Y. Mou).
}

amorphous nature of pore walls may greatly limit their uses $[3,4]$.

Sulfated zirconia $\left(\mathrm{S}-\mathrm{ZrO}_{2}\right)$ has attracted intensive attention as superacid due to its high catalytic activity in the isomerization of small hydrocarbon molecules, especially alkanes at low temperatures. $\mathrm{S}-\mathrm{ZrO}_{2}$ materials have motivated several recent reviews and ongoing studies of their applications [5-7]. Corma et al. [8] reported that higher surface areas of the original $\mathrm{ZrO}_{2}$ material corresponded to higher acid strength after sulfation. This finding suggested that the strong acid sites were associated to sites of low coordination such as defects, corners or edges found at the surface 
of small particles. It is, however, difficult to increase the surface area of zirconia through conventional preparation methods. The relatively small surface area of $\mathrm{S}-\mathrm{ZrO}_{2}$ may limit its applications.

A composite material, which can combine the advantages of mesoporous molecular sieve and $\mathrm{S}-\mathrm{ZrO}_{2}$, should greatly expand the catalytic capabilities of the material, especially in applications as strong acid catalysts for reactions containing bulky molecules. Up to now, only a few papers reported on the preparation of supported $\mathrm{S}-\mathrm{ZrO}_{2}$ on MCM-41 [9-12]. For example, Gao et al. [9] prepared $\mathrm{S}-\mathrm{ZrO}_{2} / \mathrm{MCM}-41$ by "two-step" impregnation methods. They found that the acidity of $\mathrm{S}-\mathrm{ZrO}_{2} / \mathrm{MCM}-41$ increased with the increase in $\mathrm{ZrO}_{2}$ contents. However, with Gao's method, the MCM-41 framework was destroyed when $\mathrm{ZrO}_{2}$ contents were greater than $30 \%$. Kawi et al. [10] prepared $\mathrm{S}-\mathrm{ZrO}_{2} / \mathrm{MCM}-41$ by chemical liquid deposition and hydrolysis of $\mathrm{Zr}\left(\mathrm{OPr}^{\mathrm{n}}\right)_{4}$. Their method was tedious and sample of only one $\mathrm{ZrO}_{2}$ content was reported. We previously prepared $\mathrm{S}_{-}$ $\mathrm{ZrO}_{2} / \mathrm{MCM}-41$ by using a one-step incipient wetness impregnation method with zirconium sulfate as the precursor, followed by thermal decomposition $[11,12]$. With this method, $\mathrm{S}-\mathrm{ZrO}_{2}$ was highly dispersed on MCM-41. In our previous method, calcined MCM-41 was used as starting material. However, it was difficult to maintain the crystalline structure of MCM-41 in strong acidic media such as the aqueous solution of zirconium sulfate. It was also difficult to obtain $\mathrm{S}-\mathrm{ZrO}_{2} / \mathrm{MCM}-41$ with high $\mathrm{ZrO}_{2}$ content.

In this work, we take a new approach to impregnate catalyst on the surface of mesoporous materials. Instead of impregnating on calcined porous MCM-41 materials, we chose methanol as solvent to impregnate zirconium sulfate onto the as-synthesized surfactant/silicate composite. The ion exchange process is efficient enough to induce large amount of impregnation while the mesostructure is intact. Then we use solid-state dispersion method to disperse the zirconia. Previously, Xie and Tang [13] reported that inorganic salts could be spontaneously dispersed on amorphous materials such as $\mathrm{Al}_{2} \mathrm{O}_{3}$ and $\mathrm{SiO}_{2}$. In our new method, the problem of pore fill-up can be avoided because during impregnation-dispersion process the surfactant is still mostly inside the channels.

In the following, we first report the new method of impregnating zirconium sulfate on the as-synthesized surfactant-silicate composite. Then the effect of using solid-state dispersion method to prepare $\mathrm{S}-\mathrm{ZrO}_{2} / \mathrm{MCM}-41$ composites is examined. The materials were characterized with XRD, TGA as well as surface area and pore size distribution. The catalytic activity of the resultant $\mathrm{S}-\mathrm{ZrO}_{2} /$ MCM-41 composites was studied by carrying out $n$-butane isomerization reaction.

\section{Experimental}

\subsection{Sample preparation}

As-synthesized pure siliceous MCM-41 was prepared using the delayed neutralization processes reported by Lin et al. [14].

The $\mathrm{S}-\mathrm{ZrO}_{2} / \mathrm{MCM}-41$ composites were prepared by the following steps: (1) direct impregnation of the as-synthesized MCM-41 with desired amount of zirconium sulfate/methanol solution at about $50{ }^{\circ} \mathrm{C}$ for $5 \mathrm{~h}$, (2) controlled decomposition of the template remained in MCM-41 in air at $400{ }^{\circ} \mathrm{C}$ for $10 \mathrm{~h}$, followed by solid-state dispersion of zirconium sulfate into MCM-41 and (3) decomposition of zirconium sulfate in air at $680{ }^{\circ} \mathrm{C}$ for $3 \mathrm{~h}$.

\subsection{Methods of characterization}

The powder X-ray diffraction data was collected on a Scintag X1 diffractometer using $\mathrm{Cu}-\mathrm{K} \alpha$ radiation $(\lambda=0.154 \mathrm{~nm})$. The surface area and pore size distribution measurements were carried out on a Micromeritics ASAP 2000 automatic adsorption instrument using nitrogen as the analysis gas. The TGA data were obtained with a Du Pont 2000 TG analyzer. The sulfur contents in the calcined samples were determined by inductively coupled plasma atomic emission spectrometry (ICP-AES) using a Jarrel-Ash ICP 9000 instrument. 


\subsection{Infrared studies}

Diffuse reflectance infrared Fourier transform (DRIFT) spectra of the $\mathrm{S}-\mathrm{ZrO}_{2} / \mathrm{MCM}-41$ sample after adsorbing pyridine were recorded. DRIFT spectra of the samples were recorded using a BOMEM MB155 FT-IR/Raman spectrometer. The equipment was furnished with an in situ sample cell (Harrick). The sample was pre-heated at $300{ }^{\circ} \mathrm{C}$ for $3 \mathrm{~h}$ under $10^{-6}$ mbar vacuum before pyridine vapor was introduced at room temperature, followed by evacuation for $30 \mathrm{~min}$. Spectra were acquired from room temperature to $500{ }^{\circ} \mathrm{C}$.

\subsection{Catalytic studies}

The composites of $\mathrm{S}-\mathrm{ZrO}_{2} / \mathrm{MCM}-41$ were tested as catalysts for $n$-butane isomerization in a fixed-bed continuous flow reactor. The reactor was operated at atmospheric pressure. Approximately $1.0 \mathrm{~g}$ of the catalyst was loaded into the reactor and then pretreated for $3 \mathrm{~h}$ in flowing dry air (60 $\mathrm{ml} \mathrm{min}{ }^{-1}$ ) at $450{ }^{\circ} \mathrm{C}$. The reactor temperature was then lowered to the reaction temperature of 250 ${ }^{\circ} \mathrm{C}$. The feed gas $n$-butane/ $/ \mathrm{H}_{2}$ mixtures $(1: 10 \mathrm{v} / \mathrm{v})$ flowed through the catalyst bed at $n$-butane weight hourly space velocity (WHSV) of $0.3 \mathrm{~h}^{-1}$. The flow rate was monitored using a Brooks mass flow controller. An on-line Shimadzu 14B gas chromatograph equipped with FID was used to analyze the reaction products.

\section{Results and discussion}

\subsection{Thermal decomposition analysis}

It was found that the crystalline structure and surface area of MCM-41 were better retained when as-synthesized MCM-41 was used as starting material than the calcined sample in preparation of impregnated catalysts. That is because the space-filling template inside the pores would prevent the complete fill-up of the pore volume with the impregnated precursor. Therefore, in the current preparation method, as-synthesized MCM-41 was used instead of the calcined one. TG analysis

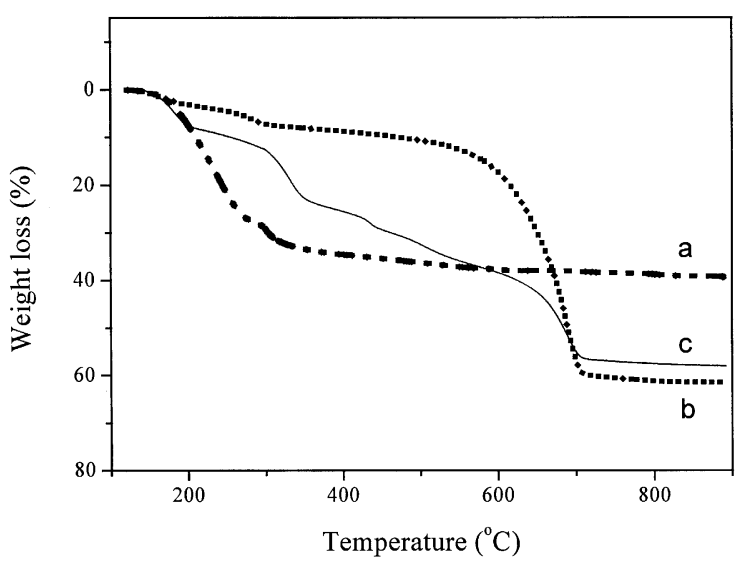

Fig. 1. TGA profiles analyzed in air (flow rate $=60 \mathrm{ml} \mathrm{min}{ }^{-1}$ ) of (a) as-synthesized MCM-41, (b) $\mathrm{Zr}\left(\mathrm{SO}_{4}\right)_{2}$ and (c) $\mathrm{Zr}\left(\mathrm{SO}_{4}\right)_{2}$ impregnated on as-synthesized MCM-41.

was carried out to determine the proper temperatures for sample preparation.

Fig. 1 shows the TGA profile taken in air of $\mathrm{Zr}\left(\mathrm{SO}_{4}\right)_{2}$ impregnated on as-synthesized MCM-41, in comparison to those of as-synthesized MCM-41 and $\mathrm{Zr}\left(\mathrm{SO}_{4}\right)_{2}$. For all the samples, we first equilibrate them at $120{ }^{\circ} \mathrm{C}$ for $1 \mathrm{~h}$ to remove water. Curve (a) shows that most of the surfactant in assynthesized MCM-41 decomposed in the temperature range of $200-350{ }^{\circ} \mathrm{C}$. Curve (b) shows that the decomposition of $\mathrm{Zr}\left(\mathrm{SO}_{4}\right)_{2}$ is negligible before $500{ }^{\circ} \mathrm{C}$, but around $600-680{ }^{\circ} \mathrm{C}$ most of $\mathrm{Zr}\left(\mathrm{SO}_{4}\right)_{2}$ decomposed.

Curve (c) is the TG profile of $\mathrm{Zr}\left(\mathrm{SO}_{4}\right)_{2}$ impregnated on as-synthesized MCM-41. There were several weight loss steps. In comparison to the other two profiles, the weight loss occurred at temperatures lower than $400^{\circ} \mathrm{C}$ is likely due to the decomposition of surfactant. The weight loss at temperature higher than $600{ }^{\circ} \mathrm{C}$ is due to the decomposition of $\mathrm{Zr}\left(\mathrm{SO}_{4}\right)_{2}$. In between these two temperatures should be a continuous decomposition of surfactant followed by a gradual decomposition of $\mathrm{Zr}\left(\mathrm{SO}_{4}\right)_{2}$. The decomposition of surfactant was apparently obstructed when $\mathrm{Zr}\left(\mathrm{SO}_{4}\right)_{2}$ was present. Two reasons may contribute to this phenomenon. One is that there is stronger interaction between sulfate and surfactants. The other is that some small $\mathrm{Zr}\left(\mathrm{SO}_{4}\right)_{2}$ crystallites may block the pore mouths of MCM-41 so that the 
surfactant and its fragments cannot evaporate as easily as that in the pristine MCM-41. On the other hand, the shift of the decomposition temperature of $\mathrm{Zr}\left(\mathrm{SO}_{4}\right)_{2}$ toward lower temperature is probably due to it small crystallite size.

\subsection{X-ray diffraction}

Fig. 2 shows the XRD patterns of $\mathrm{Zr}\left(\mathrm{SO}_{4}\right)_{2}$ impregnated on as-synthesized MCM-41 with 50 wt. $\% \mathrm{ZrO}_{2}$ loading after different heating treatment. Fig. 2(a) shows that the diffraction peaks corresponding to both the crystalline $\mathrm{Zr}\left(\mathrm{SO}_{4}\right)_{2}$ and MCM-41 structures were present after the im-

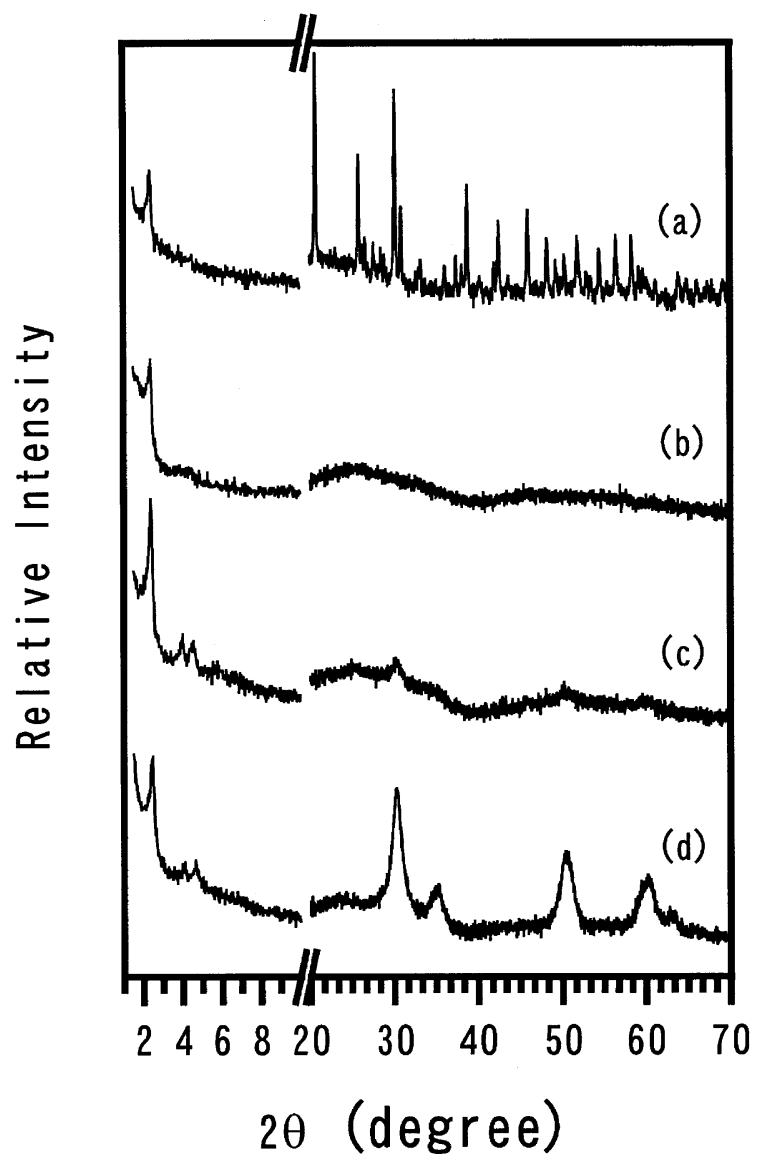

Fig. 2. XRD patterns of $\mathrm{Zr}\left(\mathrm{SO}_{4}\right)_{2}$ supported on as-synthesized MCM-41 with final composition of 50 wt. $\% \mathrm{ZrO}_{2} / \mathrm{MCM}-41$ after various heat treatments: (a) $100{ }^{\circ} \mathrm{C}, 12 \mathrm{~h}$; (b) $400{ }^{\circ} \mathrm{C}, 10 \mathrm{~h}$; (c) $400{ }^{\circ} \mathrm{C}, 10 \mathrm{~h}$ then $650{ }^{\circ} \mathrm{C}, 3 \mathrm{~h}$ and (d) $400{ }^{\circ} \mathrm{C}, 10 \mathrm{~h}$ then $680{ }^{\circ} \mathrm{C}, 3 \mathrm{~h}$. pregnated sample was dried at $100^{\circ} \mathrm{C}$. This result indicates that most of the $\mathrm{Zr}\left(\mathrm{SO}_{4}\right)_{2}$ crystallites at this stage are relatively large crystals and located on the outer surfaces of the MCM-41 particles. After the sample was heated at $400{ }^{\circ} \mathrm{C}$ for $10 \mathrm{~h}$, it is of interest to note that the characteristic peaks due to crystalline $\mathrm{Zr}\left(\mathrm{SO}_{4}\right)_{2}$ disappear completely, as shown in Fig. 2(b). According to the results of TG analysis, at $400{ }^{\circ} \mathrm{C}$ the surfactant in MCM-41 should have decomposed, but $\mathrm{Zr}\left(\mathrm{SO}_{4}\right)_{2}$ should not. The disappearance of the XRD peaks of crystalline $\mathrm{Zr}\left(\mathrm{SO}_{4}\right)_{2}$ may be explained by that $\mathrm{Zr}\left(\mathrm{SO}_{4}\right)_{2}$ moves into the channels of MCM-41 and disperses onto the interior surfaces as the surfactant has moved out. Recently, Xie et al. [15] studied the dispersion of $\mathrm{Zr}\left(\mathrm{SO}_{4}\right)_{2}$ on silica gel. They revealed that the apparent dispersion threshold of $\mathrm{Zr}\left(\mathrm{SO}_{4}\right)_{2}$ is ca. $0.26 \mathrm{~g} / 100 \mathrm{~m}^{2}$ on silica surface. The surface area of our parent MCM-41 is about $1010 \mathrm{~m}^{2} / \mathrm{g}$. In $50 \mathrm{wt} . \% \mathrm{ZrO}_{2} / \mathrm{MCM}-41$ sample, the amount of $\mathrm{Zr}\left(\mathrm{SO}_{4}\right)_{2}$ started with is very close to the apparent dispersion threshold reported in that paper.

Fig. 2(c) shows that the small peaks corresponding to tetragonal $\mathrm{ZrO}_{2}$ phase appeared when the sample was further heated at $650{ }^{\circ} \mathrm{C}$ for $3 \mathrm{~h}$. The intensity of these peaks increases when the temperature of the second heating stage was increased to $680{ }^{\circ} \mathrm{C}$ (Fig. 2(d)).

Fig. 3 shows the XRD profiles of the composites of $\mathrm{S}-\mathrm{ZrO}_{2} / \mathrm{MCM}-41$ with different $\mathrm{ZrO}_{2}$ contents. The appearance of the diffraction peaks at low angle region indicates that the ordered hexagonal arrangement of MCM-41 was still retained. In other words, the pore structure of MCM-41 was not destroyed during the solid dispersion processes. However, the intensity does decrease with the increase in $\mathrm{ZrO}_{2}$ loading.

Fig. 3 shows that in the high angle region only the diffraction peaks due to tetragonal $\mathrm{ZrO}_{2}$ phase were observed on samples of low $\mathrm{ZrO}_{2}$ contents. On the other hand, diffraction peaks corresponding to both tetragonal and monoclinic $\mathrm{ZrO}_{2}$ were observed for the samples of high $\mathrm{ZrO}_{2}$ contents. These results are consistent with that observed on silica gel supported $\mathrm{Zr}\left(\mathrm{SO}_{4}\right)_{2}$ [15]. Monoclinic $\mathrm{ZrO}_{2}$ phase was also observed when the $\mathrm{Zr}\left(\mathrm{SO}_{4}\right)_{2}$ loading was over the apparent dispersion threshold. 


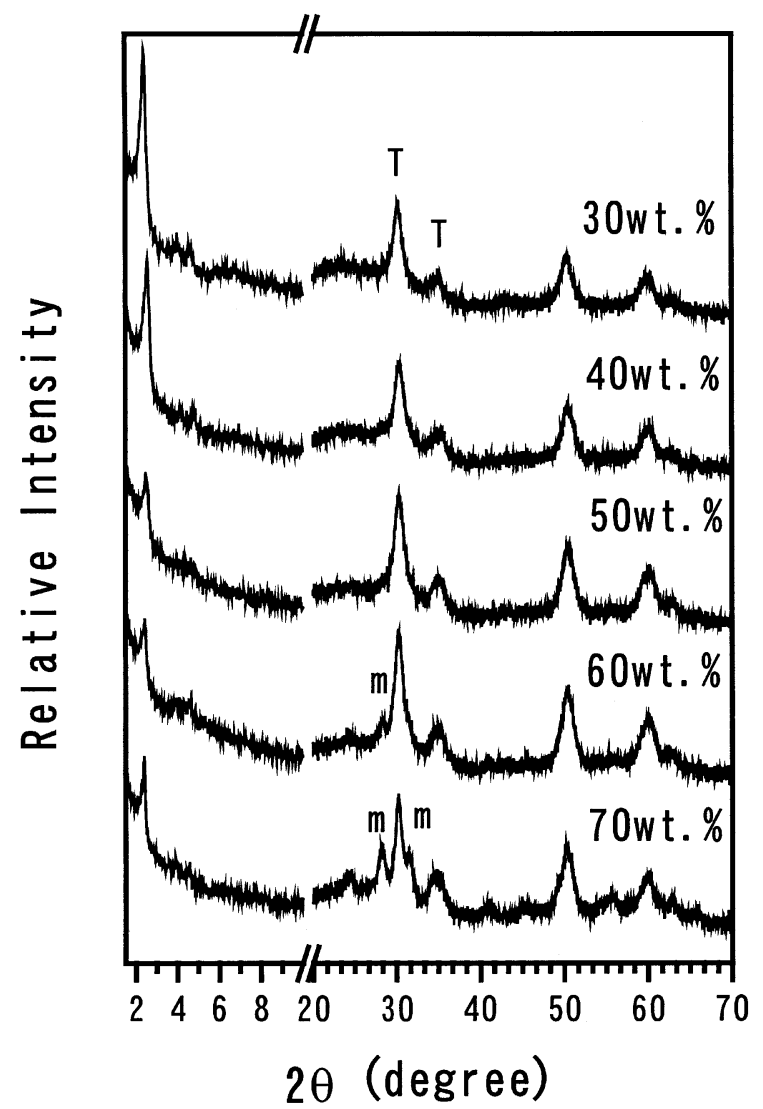

Fig. 3. XRD patterns of the composites of $\mathrm{S}-\mathrm{ZrO}_{2} / \mathrm{MCM}-41$ with different $\mathrm{ZrO}_{2}$ contents calcined at $680{ }^{\circ} \mathrm{C}$ for $3 \mathrm{~h}$ in air.

It has been reported that sulfated $\mathrm{ZrO}_{2}$ of metastable tetragonal phase has higher catalytic activity than the monoclinic phase $[16,17]$. From this point of view, among the $\mathrm{S}-\mathrm{ZrO}_{2} / \mathrm{MCM}-41$ samples, the one with about $50 \% \mathrm{ZrO}_{2}$ content should have the highest catalytic activity because this sample has the largest amount of tetragonal $\mathrm{ZrO}_{2}$.

\subsection{Physico-chemical properties of the samples}

Table 1 shows the sulfur content, BET surface area, and total pore volume of series $\mathrm{S}-\mathrm{ZrO}_{2} /$ MCM-41 samples calcined at $680{ }^{\circ} \mathrm{C}$. It can be seen that the sulfur content increases with the zirconia loading. In contrast, both the BET surface area and pore volume of the samples decrease as the zirconia content increases. Fig. 4 shows the pore size distributions in comparison to that of
Table 1

Physico-chemical properties of the samples

\begin{tabular}{llll}
\hline $\begin{array}{l}\mathrm{Wt} \% \mathrm{ZrO}_{2} \text { in } \\
\mathrm{S}-\mathrm{ZrO}_{2} / \mathrm{MCM} 41^{\mathrm{a}}\end{array}$ & $\begin{array}{l}\text { BET } \\
\text { S.A. } \\
\left(\mathrm{m}^{2} / \mathrm{g}\right)\end{array}$ & $\begin{array}{l}\text { Pore vol- } \\
\text { ume }(\mathrm{ml} / \mathrm{g})\end{array}$ & $\begin{array}{l}\text { Sulfur con- } \\
\text { tent (wt.\%) }\end{array}$ \\
\hline 30 & 667 & 0.57 & 1.34 \\
40 & 571 & 0.47 & 1.61 \\
50 & 446 & 0.41 & 1.81 \\
60 & 338 & 0.41 & 2.83 \\
70 & 301 & 0.34 & 4.95 \\
\hline
\end{tabular}

${ }^{\text {a }}$ All samples were calcined at $680{ }^{\circ} \mathrm{C}$ for $3 \mathrm{~h}$.

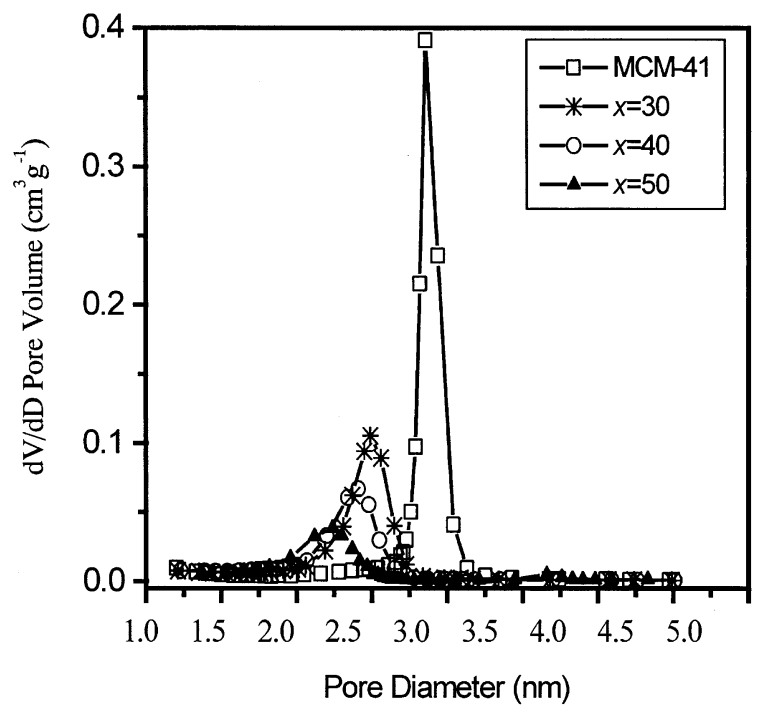

Fig. 4. The pore size distribution curves of MCM-41 and various $\mathrm{S}-\mathrm{ZrO}_{2} / \mathrm{MCM}-41$ samples (calcined at $680{ }^{\circ} \mathrm{C}$ for $3 \mathrm{~h}$ ).

parent MCM-41. The pore diameter was found to decrease gradually with the increase in zirconia loading. The pore diameter reduced from about $2.9 \mathrm{~nm}$ for the parent MCM-41 to about $2.5 \mathrm{~nm}$ for the sample of $30 \mathrm{wt} . \% \mathrm{ZrO}_{2}$, and to $\approx 2.2 \mathrm{~nm}$ for that of $50 \mathrm{wt} . \% \mathrm{ZrO}_{2}$. It is also noticeable that the pore size distributions remain rather narrow for the $\mathrm{S}-\mathrm{ZrO}_{2} / \mathrm{MCM}-41$ samples. These results confirm that the $\mathrm{S}-\mathrm{ZrO}_{2}$ is highly dispersed onto the interior surfaces of the mesopores of MCM-41.

The uniform decrease of pore size, volume and surface area is an indication that most of the loading of zirconia is inside the pores. However, at loading higher than $50 \%$ the decrease in pore volume slightly levels off and the sulfur content increases markedly as shown in Table 1 . The 50 
wt. $\% \mathrm{ZrO}_{2}$ content on MCM-41 coincides with the dispersion threshold of zirconium sulfate on MCM-41. This probably shows that further loading results in formation of zirconia particles on the external surface of MCM-41.

DRIFT spectrum of calcined MCM-41 and that of $\mathrm{S}-\mathrm{ZrO}_{2} / \mathrm{MCM}-41$ with 50 wt. $\% \mathrm{ZrO}_{2}$ were compared. The spectra shown in Fig. 5 were taken after the samples were heated at $300{ }^{\circ} \mathrm{C}$ for $1 \mathrm{~h}$ to drive away the physical adsorbed water. MCM-41 gives a strong absorption peak at $1353 \mathrm{~cm}^{-1}$, which corresponds to $\mathrm{Si}-\mathrm{O}$ stretching vibration. In absorption spectra, usually $\mathrm{Si}-\mathrm{O}$ stretching appears in the $1000-1200 \mathrm{~cm}^{-1}$ region. In the diffusereflectance spectra, the peak shifts toward higher frequencies due to differences in the specular reflectance component [18]. DRIFT spectrum also shows a sharp peak of relatively weak intensity at $3742 \mathrm{~cm}^{-1}$ in the $\mathrm{O}-\mathrm{H}$ vibration region. The latter

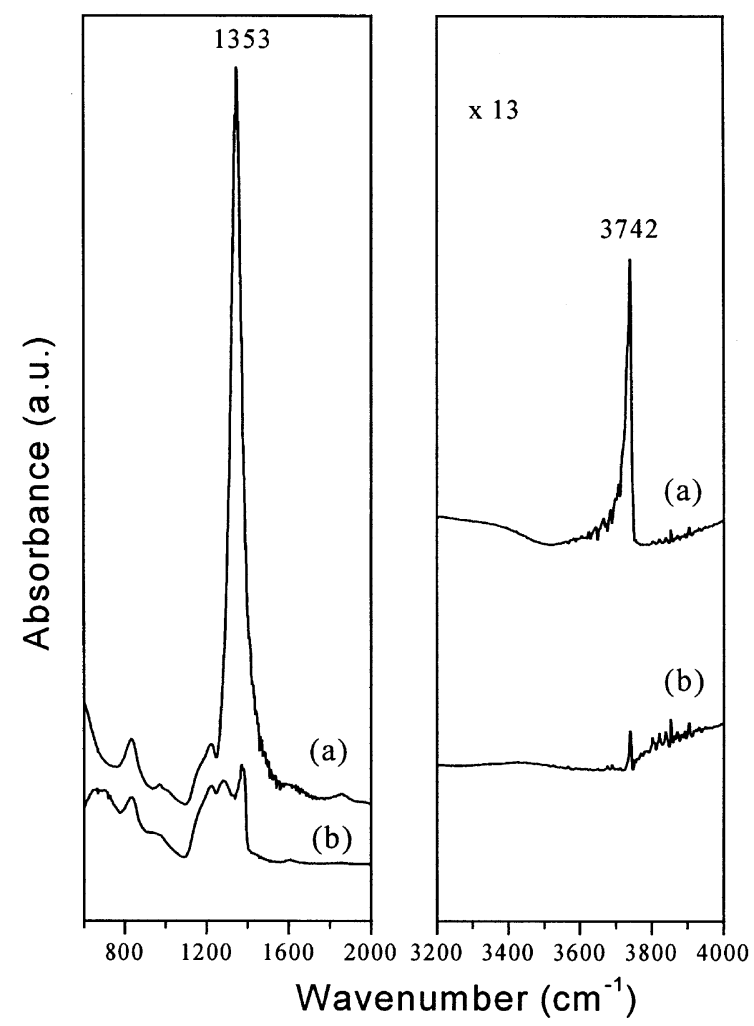

Fig. 5. DRIFT spectra of (a) calcined MCM-41 and (b) S$\mathrm{ZrO}_{2} / \mathrm{MCM}-41$ (50 wt.\% $\mathrm{ZrO}_{2}$ ) after the powder samples were heated at $300{ }^{\circ} \mathrm{C}$ for $1 \mathrm{~h}$. is associated with the free $\mathrm{SiO}-\mathrm{H}$ groups on the surface of MCM-41. The intensity of both peaks was markedly reduced when $\mathrm{S}-\mathrm{ZrO}_{2}$ was impregnated on MCM-41. These results indicate that the silica surface of MCM-41 is covered by a layer of $\mathrm{S}-\mathrm{ZrO}_{2}$ in $\mathrm{S}-\mathrm{ZrO}_{2} / \mathrm{MCM}-41$.

\subsection{Acidity of $\mathrm{S}-\mathrm{ZrO} \mathrm{O}_{2} / \mathrm{MCM}-41$}

Fig. 6 shows the DRIFT spectra of the pyridine adsorbed sample with $50 \% \mathrm{ZrO}_{2}$ loading. It can be seen that the intensity of the 1445 and $1595 \mathrm{~cm}^{-1}$ peaks decreases and that of the latter even disappears after heating the sample above $200{ }^{\circ} \mathrm{C}$. These two peaks according to Parry [19] are assigned to $\mathrm{H}$-bonding pyridine. The remaining three peaks are attributed to pyridine adsorbed on Lewis acid sites. Accompanying with the disappearance of $\mathrm{H}$-bonding pyridine, the $\mathrm{SiO}-\mathrm{H}$ vibration peak at $3742 \mathrm{~cm}^{-1}$ appears. On the other hand, the characteristic peak of pyridinium ions at $1540 \mathrm{~cm}^{-1}$ was not observed. In other words, the surface

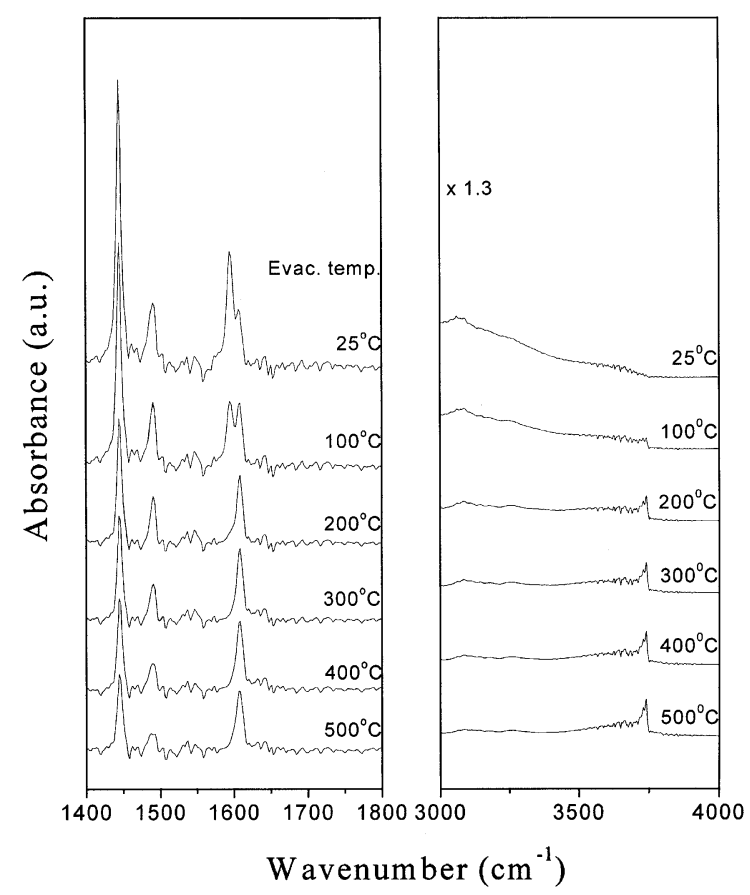

Fig. 6. DRIFT spectra of $\mathrm{S}-\mathrm{ZrO}_{2} / \mathrm{MCM}-41$ (50 wt.\% $\mathrm{ZrO}_{2}$ ) after adsorption of pyridine and evacuation at different temperatures. 
$\mathrm{SiO}-\mathrm{H}$ groups only coordinate to pyridine through $\mathrm{H}$-bonding and $\mathrm{S}-\mathrm{ZrO}_{2} / \mathrm{MCM}-41$ has only Lewis acid sites but not Brönsted acid sites. With the increase in desorption temperature from 200 to $500{ }^{\circ} \mathrm{C}$, a slight decrease in the DRIFT peak intensity was observed. However, the preservation of the three peaks associated with Lewis acid sites upon $500{ }^{\circ} \mathrm{C}$ heating of the sample implies that the strength of the Lewis acid sites on $\mathrm{S}-\mathrm{ZrO}_{2} / \mathrm{MCM}$ 41 catalyst is rather strong.

\subsection{Catalytic activity of $\mathrm{S}-\mathrm{ZrO} \mathrm{O}_{2} / M C M-41$ in $n$ - butane isomerization}

Isomerization of $n$-butane to isobutane was chosen as a model reaction to test the strong acidity of $\mathrm{S}-\mathrm{ZrO}_{2} / \mathrm{MCM}-41$ prepared by direct impregnation method. In the isomerization of $n$ butane over $\mathrm{S}-\mathrm{ZrO}_{2} / \mathrm{MCM}-41$, the selectivity to isobutane was found to be higher than $95 \%$ with only minor amounts of methane, propane and pentane being formed. The variation of the conversion at $250{ }^{\circ} \mathrm{C}$ with time on stream for $\mathrm{S}-\mathrm{ZrO}_{2} /$ MCM-41 of different $\mathrm{ZrO}_{2}$ loadings is given in Fig. 7. Generally, the initial conversion increases with the zirconia content on $\mathrm{S}-\mathrm{ZrO}_{2} / \mathrm{MCM}-41$. However, a maximum initial conversion was observed on the sample of $60 \mathrm{wt} . \% \mathrm{ZrO}_{2}$ loading. Moreover, the catalytic activities decayed with time on stream. It is noticeable that after $0.5 \mathrm{~h}$ on stream, the activity of $\mathrm{S}-\mathrm{ZrO}_{2} / \mathrm{MCM}-41$ with 50 wt.\% $\mathrm{ZrO}_{2}$ is the one giving highest activity. The 50 wt. $\% \mathrm{ZrO}_{2}$ content on MCM-41 coincides with the dispersion threshold of zirconium sulfate on MCM-41. From the XRD results, it seems to be the threshold for formation of pure tetragonal zirconia phase on MCM-41.

When comparing the catalytic activities of $\mathrm{S}-\mathrm{ZrO}_{2} / \mathrm{MCM}-41$ in $n$-butane isomerization with those of $\mathrm{S}-\mathrm{ZrO}_{2}$ supported on other supports reported in the literature, $\mathrm{S}-\mathrm{ZrO}_{2} / \mathrm{MCM}-41$ has similar activity as that supported on $\mathrm{SiO}_{2}$ [20], but lower activity than those supported on $\mathrm{Al}_{2} \mathrm{O}_{3}$ [20] and $\mathrm{Al}_{2} \mathrm{O}_{3}-\mathrm{ZrO}_{2}$ [21]. This phenomenon indicates that the different surface properties of the supports play a very important role. Al can act as a promoter to increase the catalytic activity. A small amount of $\mathrm{Al}$ was introduced into $\mathrm{S}-\mathrm{ZrO}_{2} / \mathrm{MCM}$ -

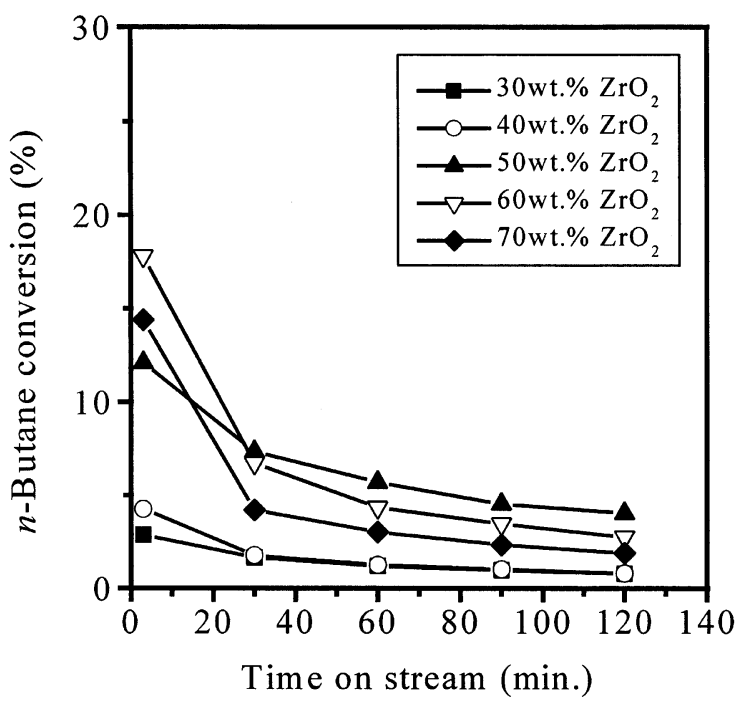

Fig. 7. Conversions of $n$-butane versus time on stream over $\mathrm{S}_{-}$ $\mathrm{ZrO}_{2} / \mathrm{MCM}-41$ (calcined at $680{ }^{\circ} \mathrm{C}$ for $3 \mathrm{~h}$ ) of different $\mathrm{ZrO}_{2}$ loadings in $n$-butane isomerization.

41, and the sample is abbreviated as SZA/MCM41. It was found that the catalytic activity in $n$ butane isomerization could be largely improved. The results are shown in Fig. 8. For comparison, the activity of $\mathrm{S}-\mathrm{ZrO}_{2}$ supported on silica gel (SZA/ $\mathrm{SiO}_{2}$ ) is also shown in Fig. 8. It is obvious that SZA/MCM-41 has much higher catalytic activity.

The high degree of dispersion of our catalyst has several advantages: (1) Its high loading of $\mathrm{S}_{-}$ $\mathrm{ZrO}_{2}$ is favorable for future detailed molecular studies of the catalytic mechanism [22]. (2) The effect of promoters can be studied more effectively with these catalysts of larger surface area. More studies on the molecular level of alkane isomerization with this effective acid catalyst system incorporated with aluminum will be reported.

\section{Conclusions}

In this article, we have successfully demonstrated that direct impregnation method is an effective way to prepare the composites of $\mathrm{S}-\mathrm{ZrO}_{2} /$ MCM-41. With this method, S- $\mathrm{ZrO}_{2} / \mathrm{MCM}-41$ of high $\mathrm{ZrO}_{2}$ loading can be easily obtained without damaging the pore structure of MCM-41. The pore size and volume were changed significantly 


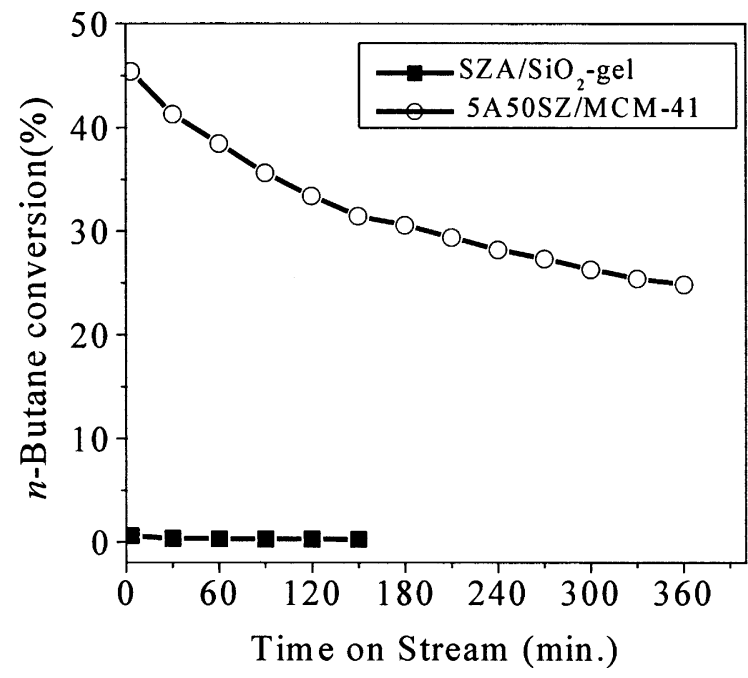

Fig. 8. Comparison of the catalytic activity for $n$-butane isomerization over SZA/MCM-41 and $\mathrm{SZA} / \mathrm{SiO}_{2}$ (both catalysts with the same $\mathrm{Al}$ and $\mathrm{Zr}$ contents were calcined at $720^{\circ} \mathrm{C}$ for $3 \mathrm{~h}$ in air).

with different $\mathrm{ZrO}_{2}$ loadings. The catalytic studies in isomerization of $n$-butane show that the resultant composites of $\mathrm{S}-\mathrm{ZrO}_{2} / \mathrm{MCM}-41$ have strong acidic properties. The $\mathrm{S}-\mathrm{ZrO}_{2} / \mathrm{MCM}-41$ catalyst with 50 wt. $\% \mathrm{ZrO}_{2}$ loading gave the highest activity after $0.5 \mathrm{~h}$ on stream.

The direct method of impregnating metal oxide catalyst into the internal surface of mesoporous materials is general. Previously, we have demonstrated its use in direct surface functionalization of mesoporous silica [23]. The surface reaction of functionalization strongly derived the direct exchange while maintaining the mesostructure. It was also applied to supporting $\mathrm{TiO}_{2}$ photocatalysts on MCM-41 [24]. By dispersing the metal containing precursors on the as-synthesized MCM-41 materials, the problem of complete fillup of the mesopores is avoided. One can thus prepared supported catalysts of rather high surface area and with narrowly distributed pore diameter.

\section{Acknowledgements}

The financial support from China Petroleum Corporation, Taiwan is gratefully acknowledged.
C.-L. Chen thanks the financial support given by the Education Commission of Jianshu Province, China (Project 00KJB530001).

\section{References}

[1] C.T. Kresge, M.E. Leonowicz, W.J. Roth, J.C. Vartuli, J.S. Back, Nature 359 (1992) 710.

[2] D. Zhao, J. Feng, Q. Huo, N. Melosh, G.H. Fredrickson, B.F. Chmelka, G.D. Stucky, Science 279 (1998) 548.

[3] A. Corma, V. Fornes, M.T. Navarro, J. Perez-Pariente, J. Catal. 148 (1994) 569.

[4] A. Sayari, Chem. Mater. 8 (1996) 1840.

[5] X.M. Song, A. Sayari, Catal Rev. Sci. Eng. 38 (1996) 329.

[6] V. Adeeva, H.Y. Liu, B.Q. Xu, W.M.H. Sachtler, Top. Catal. 6 (1998) 61.

[7] G.D. Yadav, J.J. Nair, Micropor. Mesopor. Mater. 33 (1999) 1.

[8] A. Corma, M.I. Juan-Rajadell, J.M.L. Nieto, Appl. Catal. A 116 (1994) 151.

[9] T. Lei, W.-M. Hua, Y. Tang, Y.-H. Yue, Z. Gao, Chem. J. Chinese Univ. 21 (2000) 1240.

[10] Q.-H. Xia, K. Hidajat, S. Kawi, Chem. Commun. (2000) 2229.

[11] C.-L. Chen, H.-P. Lin, S.-T. Wong, S. Cheng, C.-Y. Mou, Proceedings of the 3rd seminar on Science and Technology Catalysis, Fukuoka, Japan, March 9-10, 2000, p. 95.

[12] C.-L. Chen, S. Cheng, H.-P. Lin, S.-T. Wong, C.-Y. Mou, Appl. Catal. A 215 (2001) 21.

[13] Y.C. Xie, Y.-Q. Tang, Adv. Catal. 37 (1990) 1.

[14] H.-P. Lin, S. Cheng, C.-Y. Mou, Micropor. Mater. 10 (1997) 111.

[15] Y.-Y. Huang, B.-Y. Zhao, Y.-C. Xie, Appl. Catal. A 173 (1998) 27.

[16] C. Morterra, G. Cerrato, F. Pinna, M. Signoretto, J. Catal. 157 (1995) 109.

[17] R.L. White, E.C. Sikabwe, M.A. Coelho, P.E. Resasco, J. Catal. 157 (1995) 755.

[18] P.W. Yang, H.H. Mantsch, F. Baudais, Appl. Spectr. 40 (1986) 974 ;

G. Kortium, W. Braun, G. Herzog, Angew. Chem. 2 (1967) 333.

[19] E.P. Parry, J. Catal. 3 (1963) 371.

[20] T. Lei, J.S. Xu, Y. Tang, W.M. Hua, Z. Gao, Appl. Catal. A 192 (2000) 181.

[21] Y. Xia, W. Hua, Z. Gao, Appl. Catal. A 185 (1999) 293.

[22] T.S. Yang, T.H. Chang, C.H. Lin, C.T. Yeh, J. Mol. Catal. A 159 (2000) 397.

[23] H.-P. Lin, L.-Y. Yang, C.-Y. Mou, S.-B. Liu, H.-K. Lee, New J. Chem. 24 (2000) 253.

[24] Y.-H. Hsien, C.-F. Chang, Y.-H. Chen, S. Cheng, Appl. Catal. B. 31 (2001) 241. 